\title{
TELAAH TERHADAP PERKEMBANGAN TIPE TATANAN HUKUM DI INDONESIA PERSPEKTIF PEMIKIRAN NONET-SELZNICK MENUJU HUKUM YANG BERKEADILAN \\ Rr. Rina Antasari*
}

\begin{abstract}
The Idea of the needs for legal review of the type of Indonesian state law in order to be able to answer legal problems in the community with a sense of justice from the perspective of Nonet and Selznick's thinking. Contradictory issues at the level of legal concepts in the perspective of the development of life in Indonesian society continue to roll, some problems are found, including: 1) the implementation of law as an order system in Indonesia contradicts the implementation of the law as a disorder system; 2). The analysis between the enactment of law and social change is contradictory to the theoretical review of the development of legal orientation as a tool for social change; 3). The concept of law enforcement and social change in achieving development is contradictory to the concept of implementing legal functions as a social controller in law enforcement; and 4) Between state equipment and law enforcement in the mechanism of the criminal law system, for example, contradictions occur with the urgency of the position of advocates as a means of law enforcement in the mechanism of the criminal law system. So that the problem in this study is the development of types of legal order in Indonesia from the time of independence until now in the perspective of Nonet and Selznick's thinking and type of legal order from the perspective of Nonet Selznick's thinking that is appropriate to be applied in Indonesia that can provide a sense of justice the ideals of the Indonesian law.
\end{abstract}

Kata Kunci: Tatanan Hukum, Hukum yang Berkeadilan, Nonet-Selznick.

Hukum dan masyarakat bangsa merupakan dua hal yang tidak dapat dilepaskan satu sama lain. Akibatnya setiap pemikiran dan perkembangan terhadap hukum dari suatu masyarakat bangsa akan senantiasa mencerminkan sejarah pembentukan dan perkembangan masyarakat bangsa tersebut dalam suatu sistem. Dari perkembangan sistem hukum suatu masyarakat bangsa dapat ditangkap suasana intelektual, sosial, ekonomi dan politik bangsa pada masa yang berbeda-beda serta gagasan ideologi ke depan. Hal ini terus berlangsung tak kunjung putus sehingga merupakan bagian dari tradisi tertentu. Dengan kata lain hukum selalu memiliki hubungan yang erat dengan gagasan, maksud dan tujuan masyarakat dimana diterapkan. Sebagaimana Marcus Tulus Cicero dalam dua karyanya De Republica (tentang politik) dan De Legibus (tentang hukum) mengatakan "Ubi societis ibi ius", yang artinya dimana ada masyarakat maka disana pula harus ada hukum (Kebung, 2008: 27).

Meskipun hubungan antara hukum dan masyarakat sudah sangat jelas, akan tetapi dalam menganalisis fenomena hukum dan masyarakat masih terdapat berbagai pandangan. Misalnya, Roscoe Pound yang menganggap hukum sebagai sarana rekayasa sosial (social engineering). Dalam hal ini hukum sama halnya dengan mesin pengontrol masyarakat,

*Fakultas Syariah dan Hukum UIN Raden Fatah Palembang, Email: rinaantasari_uin@radenfatah.ac.id. 
dapat menciptakan aturan sosial yang sangat canggih dan memberikan tekanan pada individu untuk tidak melakukan tindakan yang berlawanan dengan postulat tatanan sosial yang ada. Prinsip ini diterapkan secara konsisten oleh negara bangsa modern dalam usaha menciptakan hukum nasional dan membentuk masyarakatnya (Pound, 1994: 12).

Pemikiran terhadap hukum terus berkembang yang mana menjadikan hukum tidak lagi untuk memberikan penekanan terlalu besar pada instrumen rekayasa sosial melainkan berganti pada perspektif lain yakni melihat hubungan antara hukum dan masyarakat sebagai sebuah rangkaian kesatuan yang memiliki interaksi setara. Pemikiran dimaksud diantaranya berasal dari kelompok Critical Legal Studies yang muncul sekitar tahun 1970-an di Amerika. Tokoh dari kelompok Critical Legal Studies adalah para sarjana hukum sebagian besar dari para praktisi yang terinspirasi oleh gerakan pemikiran kontinental (continental social theory) tahun 1960-an. Yang kemudian para sarjana hukum tersebut bergabung membentuk gerakan yang disebut "Gerakan Studi Hukum Kritis" (GSHK). Gerakan Studi Hukum Kritis meskipun hanya sebuah fenomena Amerika, akan tetapi telah mencoba mengemas sebuah teori yang bertujuan melawan pemikiran yang sudah mapan khususnya mengenai norma-norma dan standar yang sudah built-in dalam teori dan praktik hukum yang ada, yang cenderung sudah diterima apa adanya (taken for granted) di Amerika. Adapun hukum yang ada di Amerika pada saat itu dalam teori dan praktiknya tidak lain adalah norma-norma dan standar hukum yang didasarkan pada premis ajaran liberal legal justice. Penganut aliran tersebut percaya bahwa logika dan struktur hukum muncul dari adanya power relationships dalam masyarakat. Kepentingan hukum adalah untuk mendukung (support) kepentingan atau kelas dalam masyarakat yang membentuk hukum tersebut. Dalam kerangka pemikiran tersebut menjadikan masyarakat yang kaya dan kuat akan menggunakan hukum sebagai instrumen untuk melakukan penekanan-penekanan kedudukannya. Dengan kata lain hukum hanya dipergunakan sebagai a collection of beliefs ((Sameko, 2003: 65).

Sementara pemikiran dari kelompok Critical Legal Studies (CLS) memandang hukum mempunyai wilayah yang terbuka, menjadi domain bagi telaah disiplin lain dan hukum menjadi boleh tidak netral dan tidak obyektif. Bukankah dalam realitanya hukum merupakan konstruksi manusia, baik itu konstruksi politik, ekonomi ataupun kultural. Wacana tersebut mempertegas bahwa dalam dimensi baru hukum tidak lagi dianggap sebagai variabel independen yang terlepas dari elemen lain, akan tetapi sama-sama sebagai variabel dependen, sebagaimana halnya norma-norma sosial dan identitas budaya lainnya. Hubungan antara hukum dan masyarakat lebih sering dianggap berada dalam hubungan yang saling membentuk antara hukum negara dan tatanan normatif lainnya. (Lukito, 2008: 2). Dari sudut pandang ini hukum bukan hanya sebuah faktor pembentuk dalam masyarakat, tetapi juga sebagai faktor yang dibentuk, sehingga kajian tentang hukum tidaklah harus mencurahkan perhatian pada bagaimana para pembuat hukum berpikir tentang hukum itu akan tetapi juga bagaimana orang lain di dalam masyarakat yang mengalaminya. Sementara tipe hukum yang dijalankan sekarang, sebagaimana yang terdapat di negara-negara dunia cenderung untuk disebut sebagai hukum modern dengan ciri-ciri: pertama; berbentuk 
hukum tertulis; kedua; hukum berlaku untuk seluruh wilayah negara; dan ketiga; hukum merupakan instrumen yang dipakai secara sadar untuk membuat keputusan-keputusan politik. (Rahardjo, 2013: 213)

Ciri dan tipe hukum di atas cocok dengan tipe hukum yang ada di Indonesia sekarang ini, yang mana hukumnya cenderung berbentuk tertulis, berlaku di seluruh wilayah hukum Indonesia dan hukum dipakai secara sadar untuk membuat keputusan-keputusan politik yang sangat erat hubungannya dengan political wiill pemegang kekuasaan. Keberlakuan tipe hukum di Indonesia sekarang ini dalam kenyataannya masih banyak meninggalkan persoalan-persoalan hukum di masyarakat yang belum dapat diselesaikan dengan tuntas serta memberikan rasa keadilan. Sebagai contoh, terhadap permasalahan Tindak Kekerasan Dalam Rumah Tangga (KDRT) yang senyatanya telah ada hukum tertulis yang mengaturnya yakni UndangUndang Nomor 23 Tahun 2004 Tentang Penghapusan Tindak Kekerasan Dalam Rumah Tangga, namun dalam kenyataannya belum dapat memberikan rasa keadilan bagi korban KDRT ketika Undang-Undang tersebut ditegakkan. Korban (pada umumnya perempuan) ketika suaminya sebagai pelaku KDRT mendapat putusan Hakim harus menjalani hukuman mendekam di penjara, maka korban tersebut dan anak-anak korban akan menemui permasalahan baru yakni pembiayaan nafkah hidup yang sebelumnya ditanggung oleh suami. Permasalahan lain misalnya, terhadap Tindak Pidana Perdagangan Orang (TPPO) telah ada hukum tertulis yakni Undang-Undang Nomor 21 Tahun 2007 Tentang Pemberantasan Tindak Pidana Perdagangan Orang, Peraturan Menteri Negara Pemberdayaan Perempuan Dan Perlindungan Anak Nomor 10 Tahun 2012 Tentang Panduan Gugus Tugas Pencegahan Dan Penanganan TPPO dan Peraturan Presiden Nomor 97 Tahun 2014 Tentang Penyelenggaraan Pelayanan Terpadu Satu Pintu, senyatanya hingga saat ini penyelesaian terhadap kasus atau permasalahan TTPO belum dapat diselesaikan secara tuntas. Ironisnya angka kejahatan TPPO masih tetap ada dan cenderung meningkat di beberapa tempat di Indonesia. Hal tersebut dikarenakan berbagai faktor diantaranya, masih lemahnya penegakan hukum serta kurangnya pengetahuan dan wawasan masyarakat terhadap permasalahan TPPO. (Rina, 2018: 58).

Persoalan kontradiktif pada tataran konsep hukum dalam perspektif perkembangan kehidupan masyarakat Indonesia terus bergulir, beberapa persoalan ditemukan, diantaranya: pertama; antara implementasi hukum sebagai tatanan sistem keteraturan (order) di Indonesia kontradiktif dengan implementasi hukum sebagai tatanan sistem ketidakteraturan (disorder); kedua; analisa antara berlakunya hukum dan perubahan sosial kontradiktif dengan tinjauan teoritis terhadap perkembangan orientasi hukum sebagai alat perubahan sosial; ketiga; antara konsep penegakan hukum dan perubahan sosial masyarakat dalam pencapaian pembangunan terjadi kontradiktif dengan konsep pelaksanaan fungsi hukum sebagai pengendali sosial dalam penegakan hukum; dan keempat; antara alat perlengkapan negara terhadap penegakan hukum dalam mekanisme sistem hukum pidana misalnya, kontradiktif terjadi dengan urgensi kedudukan advokat sebagai alat penegakan hukum dalam mekanisme sistem hukum pidana. (Sanusi, 2017: 1-16).

Sehubungan dengan uraian di atas, maka salah satu wilayah hukum 
yang menarik untuk diteliti adalah mengenai hubungan yang saling membentuk antara hukum dengan norma sosial yang berproses di masyarakat, yang mana pada akhirnya diharapkan akan membentuk tipe hukum yang terspesialisasi berkesesuaian dengan keinginan masyarakatnya. Dalam hal ini Nonet dan Selznick memberikan pemikiran tentang tipe hukum yang terjadi di tengah masyarakat yakni tipe hukum represif, tipe hukum otonom dan tipe hukum responsif. Menarik untuk diteliti perjalanan tipe hukum yang pernah ada di Indonesia sejak zaman kemerdekaan hingga sekarang dari perspektif konsep tipe hukum Nonet Selznick, serta tipe hukum yang mana dari perspektif konsep tipe hukum Nonet Selznick tersebut dapat memberikan rasa keadilan bagi masyarakat Indonesia.

\section{Metode Penelitian}

Jenis penelitian yang digunakan adalah penelitian normatif yakni suatu proses penelitian dengan pertimbangan bahwa titik tolak penelitian dalam hal ini analisis terhadap konsep hukum (konsep tipe tatanan hukum Nonet dan Selznick) guna menemukan tipe hukum yang dapat menjawab permasalahan hukum yang dihadapi sesuai dengan karakter preskriptif ilmu hukum (Marzuki, 2009: 35). Sedangkan pendekatan yang dilakukan adalah pendekatan konsep (concept approach), pendekatan historis (historical approach) dan pendekatan filsafat (philosophical approach). (Ibrahim, 2006: 99).

Keseluruhan bahan hukum baik primer, sekunder maupun tersier yang sudah peneliti kumpulkan dan diklarifikasikan kemudian diolahan secara induktif (menarik kesimpulan dari sesuatu yang bersifat khusus ke umum) dan deduktif (menarik kesimpulan dari sesuatu yang bersifat khusus ke umum). Selanjutnya bahan hukum yang sudah diolah tersebut dianalis dan dihubungkan dengan konsep tipe tatanan hukum dari perspektif pemikiran Nonet Selznick, sehingga ditemukan tipe hukum yang tepat untuk diterapkan di Indonesia yang dapat memberikan rasa keadilan bagi masyarakat sesuai dengan cita hukum bangsa Indonesia. Sedangkan pengambilan simpulan dengan menggunakan metode induktif dan deduktif terhadap bahan-bahan hukum dalam penelitian ini pada akhirnya menghasilkan temuan-temuan konsep hukum baru yang menjadi dasar sekaligus sebagai kesimpulan penelitian dan mengajukan saran terhadap permasalah.

\section{Tipe Hukum Nonet Selznick dalam Konteks Perkembangan Hukum}

Nonet dan Selznick pada tahun 1970-an menjelaskan, bahwa hukum akan memberikan bentuknya sendiri dalam masyarakat. Selanjutnya dikatakan, negara yang sedang berkembang memiliki karakteristik persoalannya sendiri, oleh karena itu, tidak dapat dipaksakan untuk mengikuti cara-cara penyelenggaraan hukum yang telah mapan di negara-negara Barat. Nonet dan Selznick merupakan contoh dari arus pemikiran mengenai penyelenggaraan hukum di negara yang sedang berkembang. Keduanya mengakui pada saat suatu bangsa masih harus menghadapi masalah dasar (seperti membangun bangsa atau tatanan politik baru), dapat dimengerti adanya kemiskinan sumber daya di pihak elit penguasa. Akibatnya para pemimpin jatuh pada penggunaan kekuasaan. Inti sari pemikiran mengenai tatanan hukum yang diperkenalkan oleh Nonet \& Selznick dalarn 
tulisannnya Law \& Society in Transition: Toward Responsive Law (1978) ini adalah teori modernisasi. Teori ini mengatakan bahwa negara berkembang akan mencapai suatu tingkat perkembangan hukum yang dinikmati oleh negara-negara maju/modern, asal mau mengikuti jalan yang telah ditempuh oleh negara-negara maju tersebut.

Pada tahun 2003, tulisan Nonet dan Selznick ini diterjemahkan kedalam bahasa Indonesia, dengan judul Hukum Responsif: Pilihan di Masa Transisi. mengemukakan tiga tipe tatanan Hukum, yang dalam tingkat tertentu menunjukkan suatu perkembangan tatanan hukum dalam masyarakat yang memiliki organisasi politik dalam suatu bentuk negara. Tiga tipe tatanan Hukum itu oleh Nonet-Selznick adalah: Tatanan Hukum Represif,Tatanan Hukum Otonomius dan Tatanan Hukum yang Responsin yang akan dijelaskan di bawah ini.

a. Hukum Represif (Represif Law)

Gagasan awal dari hukum represif adalah tatanan hukum tertentu dapat berupa ketidakadilan yang tegas. Keberadaan hukum tidak menjamin keadilan, apalagi keadilan substantif. Contoh dalam hal ini adalah memandang penggunaan paksaan tanpa memikirkan kepentingan yang ada dipihak masyarakat. Menurut Nonet \& Selznick, kekuasaan pemerintah bersifat represif, jika kekuasaan tersebut tidak memperhatikan kepentingan orang-orang yang diperintah, yaitu ketika kekuasaan dilaksanakan tidak untuk kepentingan mereka, atau dengan mengingkari legitimasi masyarakat.

Represif tidak harus melibatkan penindasan yang mencolok. Represif terjadi pula ketika kekuasaan bersifat lunak namun hanya sedikit memberi perhatian dan tidak secara efektif dikendalikan oleh kepentingankepentingan penguasa. Bentuk represif yang paling jelas dalam hal ini adalah menggunakan kekerasan yang tidak terkontrol untuk menegakkan perintah, menekan pihak yang tidak patuh atau menghentikan demonstrasi. Represif juga dapat berarti dengan mendorong persetujuan pasif. Hukum Represif menunjukkan karakter-karakternya sebagai berikut: pertama; institusi hukum secara langsung dapat diakses oleh kekuatan politik, hukum diidentifikasikan sama dengan Negara. Disurbordinasikan pada tujuan negara; kedua; langgengnya sebuah otoritas merupakan urusan yang paling penting dalam administrasi hukum. Dalam perspektif resmi (Perspektif resmi membatasi tuntutan-tuntutan dengan menetapkan aturan-aturan yang kaku serta membatasi akses, penumpukan perkara di pengadilan menyusul pembaruan mengenai perluasan hak untuk memberikan pendapat menunjukkan betapa dalamnya sistem hukum tersebut tergantung kepada aksesibilitas yang terbatas), terbangun manfaat dari keraguan (The benefit of the doubt) yang masuk ke sistem. Kenyamanan administrasi menjadi titik perhatian; ketiga; lembaga-lembaga kontrol yang terspesialisasi (seperti polisi), menjadi pusat kekuasaan yang independen. Mereka terisolasi dari konteks sosial yang berfungsi memperlunak serta mampu menolak otoritas politik; keempat; sebuah rezim hukum berganda (dual law), melembagakan keadilan berdasarkan kelas dengan mengkosolidasikan dan melegitimasi pola-pola subodinasi sosial; dan kelima; hukum Pidana merefleksikan nilainilai yang dominan menunjukan moralisme hukum yang akan datang

b. Hukum Otonom (Autonomus Law) 
Dalam hukum represif, hukum mengabdi terhadap kekuasaan. Dengan lain perkataan, hukum adalah kekuasaan, baik secara lunak ataupun keras. Dalam hukum otonom, orientasi ditujukan pada pengawasan kekuasaan represif. Dengan munculnya hukum otonom, tertib hukum menjadi sumber daya untuk menjalankan hukum represif tersebut. Nonet \& Selznick, telah meringkas karakter dari hukum otonom sebagai berikut: pertama; hukum terpisah dari politik, khas, sistem hukum ini menyatakan kemandirian kekuasaan peradilan dan membuat garis tegas antara fungsi legislatif dan politik; kedua; tertib hukum mendukung model peraturan (model of rules). Fokus peraturan membantu menerapkan ukuran bagi akuntabilitas para pejabat maupun risiko campur tangan lembaga-lembaga hukum itu dalam wilayah politik; ketiga; prosedur adalah jantung hukum. Keteraturan dan ketertiban (fairnes) (bukan keadilan subtantif), merupakan tujuan utama dan kompetensi utama dari tertib hukum, dan; keempat; ketaatan pada hukum dipahami sebagai kepatuhan yang sempurna terhadap peraturan hukum positif kritik terhadap hukum harus disalurkan melalui proses politik.

Hukum otonom pada prinsipnya berpusat kepada hakim dan terikat pada peraturan. Hakimlah yang menjadi sumber tatanan hukum, bukan polisi atau legislator. Di sini hakim memasukkan nilai-nilai otonomi hukum, kewajaran, serta retribusi dan dengan demikian menjadi penting secara simbolis. la adalah juru bicara bagi hukum sebagai keadilan dan bukan hukum sebagai keinginan politik. Peraturan yang dijalankan oleh hakim tersebut diartikan sebagai sebuah norma dengan cakupan dan aplikasi yang sudah tertentu sifatnya.

c. Hukum Responsif (Responsive Law)

Nonet \& Selznick sampai kepada pencarian hukum yang responsif. Menurut mereka pencarian hukum responsif telah menjadi kegiatan teori hukum modern yang terus-menerus dilakukan, seperti yang telah dikatakan Jeroma Frank. Tujuan utama dari penganut realisme hukum (legal realism) adalah untuk membuat hukum menjadi lebih responsif terhadap kebutuhan sosial. Hukum responsif mempunyai karakteristik berikut: pertama; dinamika perkembangan. hukum meningkatkan otoritas tujuan dalam pertimbangan hukum; kedua; tujuan membuat kewajiban hukum semakin problematik, sehingga mengendurkan klaim hukum terhadap kebutuhan dan membuka kemungkinan bagi suatu konsepsi tatanan publik yang semakin tidak kaku dan semakin bersifat perdata (Civil sebagai lawan dari publik), dan; ketiga; karena hukum memiliki keterbukaan dan fieksibilitas, advokasi hukum memasuki dimensi politik yang meningkatkan kekuatan yang dapat membantu mengoreksi dan mengubah institusi hukum, namun yang juga mengancam memperlemah intregasi institusional.

Ketiga tatanan hukum tersebut merupakan bentuk dari hukum modern, yang tidak lepas dari adanya pengaruh dari negara modern. Selain itu, ketiga tatanan tersebut termasuk kajian kepada sosiologi hukum. Berdasarkan uraian di atas, tatanan hukum otonom sangat menonjol dalam praktek hukum yang tengah terjadi sekarang ini. Keotonoman hukum ini, bukan menjadi harga mati, atau penilaian yang final tetapi hanya merupakan ide dari Nonet \& Selznick dan juga kita akui bahwa sekarang ini tengah terjadi keotonoman. Hal ini diperkuat dengan gagasan bahwa prosedur merupakan jantung dari hukum dan menempati etos penting dalam 
hukum otonom. Hukum otonom dimulai dengan komitmen untuk memerintah berdasarkan peraturan. Hukum otonom ini menganggap bahwa prosedur merupakan jaminan paling nyata dari suatu penerapan peraturan secara adil. Hukum otonom, mengendalikan sifatnya yang represif dengan due process. Dalam penyelesaian pertikaian antar penduduk dan dalam penilaian klaim-klaim oleh atau melawan negara, sistem hukum menawarkan produknya yang paling nyata dan tegas (keadilan prosedural). Dalam praktek-praktek di pengadilan (misalnya), kedekatan antara hukum dengan prosedural sangat nyata. sekali. Keduanya tidak mempunyai jarak. Bagi siapa saja yang berurusan dengan pengadilan, ia harus melewati prosedur-prosedur yang telah ditetapkan. Dalam tatanan hukum otonom ini, pengadilan diberi kekuasaan untuk menentukan prosedurnya sendiri, yaitu mengatur syarat-syarat untuk mendapat akses dalam proses hukum dan cara-cara berpartisipasi di dalam proses hukum tersebut. Dengan adanya kekuasaan ini, pengadilan dapat menuntut bahwa siapapun yang dapat menggugat otoritas hukum, harus melakukan dengan cara yang konsisten dengan keteraturan hukum.

Akibat dari penggunaan prosedur tersebut, pengadilan hanya menghasilkan keadilan yang sifatnya formal. Padahal tidak dapat dipungkiri bahwa keadilan yang sifatnya formal, secara konsisten melayani pola-pola hak istimewa dan kekuasaan yang ada. Makna keadilan dirusak ketika sebuah sistem bangga akan adanya sistem peradilan yang sempurna dan tidak memihak. Tidak mampu menjustifikasi gugatan akan ketidakadilan substantif. Keadilan yang ditawarkan oleh due process dalam tatanan hukum otonom ini terasa menyesatkan dan sewenang-wenang, ketika ia menghalangi terwujudnya harapan akan keadilan. la dilindungi oleh prosedur-prosedur yang penuh keberpihakan, dengap cara-cara itu seolaholah pengadilan tengah melayani status.

Berdasarkan uraian di atas dapat disimpulkan, bahwa hukum represif, otonom, dan responsif dapat dipahami sebagai tiga dilema yang ada antara integritas dan keterbukaan. Hukum yang represif ditandai dengan adaptasi yang pasif dan oportunistik dari institusi-institusi hukum terhadap lingkungan sosial dan politik. Hukum otonom merupakan suatu reaksi yang menentang keterbukaan yang serampangan. Perhatian utamanya adalah bagaimana menjaga integritas institusional. Untuk mencapai tujuan tersebut, hukum mengisolasi dirinya, mempersempit tanggung jawabnya dan menerima formalisms yang buta demi mencapai sebuah integritas. Tipe hukum responsif, berusaha untuk mengatasi ketegangan yang demikian tersebut. Ciri khas hukum responsif adalah mencari nilai-nilai tersirat yang terdapat dalam peraturan dan kebijakan. Dalam tatanan hukum responsif, due process dipahami sebagai nama untuk serangkaian peraturan yang dipaparkan secara historis, yang melindungi hak-hak atas pemberitahuan (right of notice) untuk didengar dalam persidangan dengan sistem juri. Makna due process ini bertentangan dengan interpretasi yang lebih fleksibel, yang mengangap bahwa aturan terkait pada masalah-masalah konteks yang khusus dan berusaha untuk mengidentifikasikan nilai-nilai yang dipertaruhkan dalam perlindungan melalui prosedur. Ketika nilai-nilai ini diartikulasikan, nilai-nilai tersebut menawarkan kriteria otoritatif untuk mengkritisi peraturan-peraturan yang ada, mendorong pembentukan baru, dan menuntut perluasan sistem due process ke situasi kelembagaan baru. 
Akhirnya, tuntutan terhadap due process ini adalah, perlunya tatanan nilai-nilai yang lebih mengarah kepada pembentukan hukum responsif. Alasannya adalah karena peraturan perlu bergantung kepada atau disesuaikan dengan kondisi-kondisi historis yang tepat, sehingga is bisa relevan dan mempunyai daya hidup. Ketika lingkungan berubah, peraturanperaturan harus ditata ulang, bukan hanya untuk memenuhi kebutuhan kebijakan, namun juga untuk melindungi otoritas peraturan itu sendiri dan integritasnya ketika diaplikasikan.

Tabel I: Tiga Hukum Menurut Nonet dan Selznick

\begin{tabular}{|c|c|c|c|}
\hline & $\begin{array}{c}\text { HUKUM } \\
\text { REPRESIF }\end{array}$ & $\begin{array}{l}\text { HUKUM } \\
\text { OTONOM }\end{array}$ & $\begin{array}{c}\text { HUKUM } \\
\text { RESPONSIF }\end{array}$ \\
\hline TUJUAN & Ketertiban & Legitimasi & Kompetensi \\
\hline LEGITIMASI & $\begin{array}{l}\text { Ketahanan } \\
\text { Sosial dan } \\
\text { tujuan negara } \\
\text { (raison de'etat) }\end{array}$ & $\begin{array}{l}\text { Keadilan } \\
\text { procedural }\end{array}$ & $\begin{array}{l}\text { Keadilan } \\
\text { subtantif. }\end{array}$ \\
\hline PERATURAN & $\begin{array}{l}\text { Keras dan rinci } \\
\text { namun berlaku } \\
\text { lemah terhadap } \\
\text { pembuat hukum }\end{array}$ & $\begin{array}{l}\text { Luas dan rinci, } \\
\text { mengikat } \\
\text { pengua-sa dan } \\
\text { yang dikuasai }\end{array}$ & $\begin{array}{l}\text { Subordinat dari } \\
\text { prinsip dan } \\
\text { kebijakan }\end{array}$ \\
\hline PERTIMBANGAN & $\begin{array}{l}\text { Ad hoc, } \\
\text { memudah-kan } \\
\text { mencapai tujuan } \\
\text { dan bersifat } \\
\text { partikular }\end{array}$ & $\begin{array}{l}\text { Sangat melekat } \\
\text { pada otoritas } \\
\text { legal, rentan } \\
\text { terhadap } \\
\text { formalisme dan } \\
\text { legalisme }\end{array}$ & $\begin{array}{l}\text { Purposif } \\
\text { (berorientasi } \\
\text { tujuan) perluasan } \\
\text { kompetensi } \\
\text { kognitif. }\end{array}$ \\
\hline DISKRESI & $\begin{array}{l}\text { Sangat luas, } \\
\text { oportunistik }\end{array}$ & $\begin{array}{l}\text { Dibatasi oleh } \\
\text { peraturan, } \\
\text { delegasi yang } \\
\text { sempit. }\end{array}$ & $\begin{array}{l}\text { Luas tetapi sesuai } \\
\text { dengan tujuan }\end{array}$ \\
\hline PAKSAAN & $\begin{array}{l}\text { Ekstensif, } \\
\text { dibatasi secara } \\
\text { lemah }\end{array}$ & $\begin{array}{l}\text { Dikontrol oleh } \\
\text { batasan- } \\
\text { batasan hukum }\end{array}$ & $\begin{array}{l}\text { Pencarian positif } \\
\text { bagi berbagai } \\
\text { alternatif, seperti } \\
\text { insentif, sistem } \\
\text { kewajiban yang } \\
\text { mampu bertahan } \\
\text { sendiri }\end{array}$ \\
\hline MORALITAS & $\begin{array}{l}\text { Moralitas } \\
\text { komunal, } \\
\text { moralisme } \\
\text { hukum, } \\
\text { "moralitas } \\
\text { pembatasan" }\end{array}$ & $\begin{array}{l}\text { Moralitas } \\
\text { kelembagaan } \\
\text { yakni dipenuhi } \\
\text { dengan } \\
\text { integritas } \\
\text { proses hukum }\end{array}$ & $\begin{array}{l}\text { Moralitas sipil: } \\
\text { "Moralitas } \\
\text { kerjasama" }\end{array}$ \\
\hline POLITIK & $\begin{array}{l}\text { Hukum } \\
\text { subordinat } \\
\text { terhadap politik } \\
\text { kekuasaan }\end{array}$ & $\begin{array}{l}\text { Hukum } \\
\text { independen dari } \\
\text { politik, } \\
\text { pemisahan } \\
\text { kekuasaan }\end{array}$ & $\begin{array}{l}\text { Terintegrasinya } \\
\text { aspirasi hukum } \\
\text { dan politik, } \\
\text { keberpaduan } \\
\text { kekuasaan }\end{array}$ \\
\hline $\begin{array}{l}\text { HARAPAN \& } \\
\text { KETAATAN }\end{array}$ & $\begin{array}{l}\text { Tanpa syarat, } \\
\text { ketidaktaatan }\end{array}$ & $\begin{array}{l}\text { Penyimpangan } \\
\text { peraturan yang }\end{array}$ & $\begin{array}{l}\text { Pembangkangan } \\
\text { dilihat dari aspek }\end{array}$ \\
\hline
\end{tabular}




\begin{tabular}{|c|c|c|c|}
\hline & $\begin{array}{l}\text { perse dihukum } \\
\text { sebagai } \\
\text { pembangkang }\end{array}$ & $\begin{array}{l}\text { dibenarkan, } \\
\text { untuk menguji } \\
\text { validitas } \\
\text { undang-undang } \\
\text { atau perintah }\end{array}$ & $\begin{array}{l}\text { bahaya subtantif, } \\
\text { dipandang sebagai } \\
\text { gugatan terhadap } \\
\text { legitimasi. }\end{array}$ \\
\hline PARTISIPASI & $\begin{array}{l}\text { Pasif, kritik } \\
\text { dilihat sebagai } \\
\text { ketidaksetiaan }\end{array}$ & $\begin{array}{l}\text { Akses dibatasi } \\
\text { prosedur baku, } \\
\text { munculnya kritik } \\
\text { atas hukum }\end{array}$ & $\begin{array}{l}\text { Akses diperbesar } \\
\text { dengan integrasi } \\
\text { advokasi hukum } \\
\text { dan sosial }\end{array}$ \\
\hline
\end{tabular}

Sumber: diolah dari sumber sekunder dalam penelitian ini

Dari bagan di atas, dapat dijelaskan, pertama, Nonet \& Selznick menceritakan tentang hubungan antara hukum dan penindasan. Menurut mereka, masuknya pemerintah ke dalam pola kekuasan yang bersifat menindas melalui hukum, berkaitan erat dengan masalah kemiskinan sumber daya pada elit pemerintah. Biasanya, penggunaan kekuasaan yang bersifat menindas terdapat pada masyarakat yang berada dalam tahap pembentukan suatu tatanan politik tertentu. Hukum represif muncul karena definisi baru kepemilikan sebagai hak eksklusif seseorang, yang diragukan keabsahannya dan karena timbulnya kejahatan di kalangan rakyat (Peters \& Siswosoebroto, tt: 210). Untuk dapat mengerti bagaimana hukum represif itu terbentuk dalam masyarakat, perhatikanlah ungkapan di bawah ini.

“...Seorang perancang Undang-Undang sejati tidak perlu takut apa-apa kecuali kesalahan, namun kepentingan perundangundangan hanya mengenal rasa takut akan akibat-akibat dari hak-hak (yaitu terkucilkannya kaum miskin dari segala hasil dari pemilikan), takut akan para pelaku kejahatan yang menjadi sasaran pembuatan hukum. Kekejaman merupakan ciri khan dari hukum yang didikte oleh perasaan pengecut, karena kepengecutan hanya bisa bekerja kuat dengan berlaku kejam. Akan tetapi, kepentingan pribadi selalu bersifat pengecut, karena jantungnya, jiwanya, merupakan suatu objek ekstern yang selalu bisa direnggut clan dilukai clan siapakah yang hatinya tidak bergetar menghadapi bahaya kehilangan jantung dan jiwa? Bagaimana seorang perancang undang-undang yang hanya mementingkan diri sendiri bisa berperikemanusiaan, bila sesuatu yang tidak berperikemanusiaan, suatu hakikat materi yang asing, menjadi hakikat paling tinggi dalam dirinya. Quad it a peur, it est terrible (kalau takut, ia mengerikan). Kata National, mengenai guizot. Kata-kata ini clapat ditulis sebagai motto di atas semua Perancangan Undang-undang yang diilhami oleh kepentingan diri dan karenanya jugs oleh perasaan pengecut (Mew 1: 121).

Berdasarkan ungkapan di atas, dapat disimpulkan bahwa pembuatan Undang-Undang semacam itu berada pada tatanan hukum yang represif. Hal itu mengindikasikan bahwa setiap hukum represif merupakan keadilanyangbeku. Hukum represif tidak mengidentikkan dirinya dengan kekuasaan semata karena dengan fungsi yang represif, hukum ini dapat diharapkan membuat kekuasaan lebih efektif. (Wahid \& Rumadi, 2001: 35). Kemudian Nonet \& Selznik menceritakan pada bagian hukum otonom bahwa hukum represif dikontraskan dengan hukum otonom. Hukum otonom adalah hukum sebagai suatu institusi tersendiri, yang mampu menjinakkan 
penindasan dan melindungi integritasnya sendiri. Akan tetapi, hukum represif tidak akan pernah hilang begitu saja dari tatanan hukum yang ada sebab hukum represif ini bergantung kepada orang bawah (masyarakat kecil), yang sumber utamanya adalah kemiskinan akan sumber-sumber daya politik.

Usaha menemukan hukum yang responsif sangat mewarnai teori hukum modern. Seperti yang dikatakan Jerome Frank, tujuan utama para realis hukum adalah membuat hukum menjadi lebih responsif (tanggap) pada kebutuhan sosial. (Nonet, Selznick, dan Kagan, 2017). Untuk tujuan itu mereka mendesak diperluasnya bidang-bidang yang relevan untuk dijangkau hukum, sehingga pola pikir hukum dapat mencakup pengetahuan tentang konteks sosial dan dampak kebijakan atau tindakan pemerintah.

Teori Pound tentang kepentingan sosial merupakan upaya yang lebih eksplisit untuk menciptakan suatu model hukum yang reponsif. Dalam perspektif ini, hukum yang baik harus menawarkan sesuatu yang lebih dari keadilan prosedural. Hukum itu harus berkemampuan fair (adil, memberi kesempatan yang sama), hukum itu harus membantu menentukan kepentingan masyarakat dan commited pada tercapainya keadilan yang substansial (hakiki) (Pound, 1959: 50). Untuk dapat menjadi responsif, sistem hukum harus bersifat terbuka untuk ditantang. Hal ini menunjukkan bahwa di sana-sini selalu ada keterkaitan, harus mampu membangkitkan partisipasi dan harus dapat memahami dan menerima kebutuhan-kebutuhan sosial ekonomi yang baru. (Brugginnk, 1996: 138).

Hukum yang represif, otonom, dan responsif dapat dipahami sebagai tiga reaksi atas dilema integritas dan keterbukaan. Ciri hukum yang represif adalah adaptasi lembaganya yang pasif dan oportunistik terhadap lingkungan sosial dan politiknya. Hukum Otonom adalah reaksi terhadap keterbukaan yang mutlak dan tidak pandang bulu. Titik beratnya adalah dipertahankannya integritas kelembagaan untuk mencapai tujuan. Hukum ini mengisolasi diri, mempersempit tanggung jawabnya dan menerima formalisme buta sebagai harga pencapaian integritas penegakan hukum. Sedangkan tips hukum yang ketiga, mencoba mengatasi ketegangan itu. Responsif bukan semata-mata terbuka (seperti yang disebut Brugginnk di atas) atau adaptif, namun lebih menunjukan bahwa hukum tersebut harus memiliki kemampuan untuk bertanggungjawab. Oleh karena itu, adaptasinya khusus dan selektif. Suatu institusi yang responsif akan mempertahankan pandangan tentang apa yang penting bagi integritasnya, sambil memikirkan kebutuhan- kebutuhan baru yang ada dalam lingkungannya.

Dalam masa transisi dari otonom ke responsif, langkah yang menentukan adalah menggeneralisasi tujuan hukum. Aturan- aturan kebijakan dan prosedur tertentu dianggap sebagai alat dan bisa dikorbankan. Bisa saja hal itu dihargai sebagai pengalaman, tetapi tidak lagi menentukan atau memberikan batasan-batasan terhadap komitmen tatanan hukum. Sebagai gantinya, tekanannya bergeser pada tujuan-tujuan yang lebih umum, yang mengandung premis-premis kebijakan dan mengungkapkan urusan yang sebenarnya kita hadapi. Oleh karena itu, ciri hukum yang responsif adalah pencarian nilai-nilai implisit yang ada di dalam aturan-aturan dan kebijakan. Sebagai contoh yang tidak asing adalah hukum kelayakan proses/proses hukum yang layak (law of due process). 
Sebagai suatu doktrin konstitusional due Process dapat saja di anggap sebagai sekedar sebagai nama bagi sekumpulan aturan yang ditentukan secara historis, yang melindungi hak atas pemberitahuan, hearing, pemeriksaan oleh juri dan sejenisnya.

Due Process yang sudah tertentu ini berlawanan dengan interpretasi (penafsiran) yang lebih fleksibel, yang menganggap aturan terikat pada masalah-masalah dalam konteks yang khusus dan berusaha mengidentifikasi nilai-nilai yang dipertaruhkan dalam perlindungan melalui prosedur. Ketika nilai-nilai ini dikemukakan, mereka menawarkan kriteria kuat untuk mengkritik aturan yang ada, membuat aturan baru dan membimbing perluasan cakupan due process ke situasi kelembagaan baru merupakan sumber utama. Demikian pula, generalisasi tujuan dari fleksibilitas dalam, organisasi modern. Misalnya, dalam penyelesaian kasus KDRT, penegak hukum mengambil langkah menuju sifat responsif ketika itu menyadari perlunya membedakan apakah kejahatan dalam persolan KDRT sama dengan kejahatan sejenis yang terjadi antar pelaku dan korban yang tidak lembaga perkawinan (di luar ranah rumah tangga).

Bentuk tatanan hukum yang reponsif ini sulit diwujudkan. Institusiinstitusi dan birokrasi (sangat rentan) karena sebenarnya mereka sematamata hanya ingin cuci tangan dan mendapat kebenaran dari suatu proses. Namun realitas memperlihatkan jangkauan hukum negara berhadapan dengan pluralisme hukum yang tidak dapat dihindari dan terjadi di Indonesia. Persoalan tersebut akan berhubungan erat dengan nilai-nilai normatif yang berasal dari kenyataan yang tumbuh di masyarakat. Dalam tradisi masyarakat Indonesia dibangun berdasarkan tiga tradisi hukum utama (Lukito, 2008: 28) yakni hukum adat, hukum Islam dan Hukum tradisional. Hukum adat pada dasarnya adalah tradisi hukum yang terbentuk berdasarkan nilai-nilai normatif masyarakat pribumi dan berkembang lebih jauh dalam masyarakat pribumi sesuai dengan rasa keadilan dan harmoni setempat (sebagai sistem hukum bersahaja). Soepomo menjelaskan untuk menyelami hukum adat dalam sistemnya maka harus menyelami dasar-dasar alam pikiran yang hidup di dalam masyarakat itu. Dan untuk itu harus diteliti susunan persekutuan-persekutuan hukum di lapangan rakyat yaitu organisasi desa, nagari,hutan dan seterusnya. Tradisi hukum Islam adalah tradisi normatif yang datang ke nusantara bersaman dengan berkembangnya penyebaran Islam di wilayah tersebut. Sumbernya berasal dari wahyu tuhan dan dipatuhi karena diyakini. Terakhir tradisi hukum sipil yang sampai ke Nusantara seiring dengan terjadinya kolonialisasi Belanda. Hal ini adalah hukum barat yang sukses diimpor ke wilayah ini sebagai hasil imposisi hukum yang lama dan berkelanjutan oleh penguasa kolonial ke dalam kehidupan masyarakat pribumi. Dalam proses penjelasan ajaran-ajaran dasar tradisi-tradisi tersebut harus dapat menjelaskan the pimary rule of dan hermeneutik (yang menjadi fondasi bangunan tradisi tersebut). (Soepomo, 2000: 22).

Kondisi pluralisme lebih lanjut menurut Woodman mendifinisikannya yakni: suatu kondisi dimana masyarakat melihat adanya lebih dari satu sistem hukum. Masyarakatnya dapat menggambarkan dirinya merupakan objek dari dua sistem hukum atau lebih yakni hukum negara dan satu atau lebih tradisi hukum etnik atau agama. (Lukito, 2008: 9). Pengaruh agama, sosial budaya terkadang menghadang dan terkadang kurang dipahaminya, 
sehingga keadilan substansi tidak terwujud. Sementara kondisi politik (partisipasi politik) yang berkepentingan menjadi terangkat. Terhadap Hukum responsif memiliki kelemahan juga yakni konsep hukum responsif kurang mantap, sangat rentan dan sangat rapuh jaring-jaring penunjangnya untuk mewujudkan tatanan hukum tersebut.

\section{Tatanan Hukum di Indonesia Menuju Hukum yang Berkeadilan Perspektif Pemikiran Nonet dan Selznick}

Usaha menemukan hukum yang lebih tanggap dengan fenomena kehidupan di tengah masyarakat sangat mewarnai perkembangan pembelajaran tentang hukum modern. Seperti yang dikatakan Jerome Frank, tujuan utama para realis hukum adalah membuat hukum mejadi lebih tanggap (responsive) pada kebutuhan sosial. Untuk tujuan itu mereka mendesak diperluasnya bidang-bidang yang relevan untuk dijangkau hukum, sehingga pola pikir hukum dapat mencakup pengetahuan tentang konteks sosial dan dampak kebijakan atau tindakan pemerintah. (Nonet, dan Selznick, 2008).

Teori Pound tentang kepentingan sosial merupakan upaya yang lebih eksplisit untuk menciptakan suatu model hukum yang reponsif. Dalam perspektif ini, hukum yangbaik harus menawarkan sesuatu yang lebih dari keadilan prosedural. Hukum itu harus berkemampuan fair (adil, memberi kesempatan yang sama), hukum itu harus membantu menentukan kepentingan masyarakat dan commited pada tercapainya keadilan yang substansial (hakiki). Untuk dapat menjadi responsif, sistem hukum harus bersifat terbuka untuk ditantang. Hal ini menunjukkan bahwa disana-sini selalu ada keterkaitan, (Pound, 1959: 50). harus mampu membangkitkan partisipasi dan harus dapat memahami dan menerima kebutuhan-kebutuhan sosial ekonomi yang baru. Hal tersebut sebenarnya akan sangat ditunjang oleh perkembangan ekonomi, sosial dan politik, ketiga bagian tersebut memiliki peranan sentral. Sistem ekonomi yang bebas, yang dituangkan dalam ketentuan kebebasan berkontrak, memungkinkan sistem perdagangan bebas yang mendorong membaiknya kondisi sosial. Dengan terjadinya hubungan harmonis antar berbagai golongan dalam masyarakat, iklim politik dimungkinkan menjadi sehat melalui sistem pemisahan dan pendistribusian kekuasaan yang jelas. Menurut Teori Mohl, karakteristik dari negara hukum adalah Equality before the Law, yang melindungi kebebasan hak-hak warga negara dan kepentingankepentingan publik dan bertujuan pencapaian kebebasan personal. Ini merupakan konsep material dari negara hukum. (Neumann, 1966: 186).

Hukum yang represif, otonom, dan responsif dapat dipahami sebagai tiga reaksi atas dilema integritas dan keterbukaan. Ciri hukum yang represif adalah adaptasi lembaganya yang pasif dan oportunistik terhadap lingkungan sosial dan politiknya. Hukum Otonom adalah reaksi terhadap keterbukaan yang mutlak dan tidak pandang bulu. Titik beratnya adalah dipertahankannya integritas kelembagaan untuk mencapai tujuan. Hukum ini mengisolasi diri, mempersempit tanggung jawabnya dan menerima formalisms buta sebagai harga pencapaian integritas penegakan hukum. Sedangkan tips hukum yang ketiga, mencoba mengatasi ketegangan itu. Responsif bukan semata-mata terbuka (seperti yang disebut Brugginnk di atas) atau adaptif, namun lebih menunjukan bahwa hukum tersebut harus memiliki kemampuan untuk bertanggungjawab. Oleh karena itu, 
adaptasinya khusus dan selektif. Suatu institusi yang responsif akan mempertahankan pandangan tentang apa yang penting bagi integritasnya, sambil memikirkan kebutuhan-kebutuhan baru yang ada dalam lingkungannya. Dalam masa transisi dari otonom ke responsif, langkah yang menentukan adalah menggeneralisasi tujuan hukum. Aturanaturan kebijakan dan prosedur tertentu dianggap sebagai alat dan bisa dikorbankan. Bisa saja hal tersebut dihargai sebagai pengalaman, tetapi tidak lagi menentukan atau memberikan batasan-batasan terhadap komitmen tatanan hukum. Sebagai gantinya, tekanannya bergeser pada tujuan-tujuan yang lebih umum, yang mengandung premis-premis kebijakan dan mengungkapkan urusan yang sebenarnya dihadapi. Oleh karena itu, ciri hukum yang responsif adalah pencarian nilai-nilai implisit yang ada di dalam aturan-aturan dan kebijakan. Sebagai contoh yang tidak asing adalah hukum kelayakan proses/proses hukum yang layak (law of due process). Sebagai suatu doktrin konstitusional due Process bisa saja dianggap sebagai sekedar sebagai nama bagi sekumpulan aturan yang ditentukan secara historis, yang melindungi hak atas pemberitahuan, hearing, pemeriksaan oleh juri dan sejenisnya.

Due Process yang sudah tertentu ini berlawanan dengan interpretasi (penafsiran) yang lebih fleksibel, yang menganggap aturan terikat pada masalah-masalah dalam konteks yang khusus dan berusaha mengidentifikasi nilai-nilai yang dipertaruhkan dalam perlindungan melalui prosedur. Ketika nilai-nilai ini dikemukakan, mereka menawarkan kriteria kuat untuk mengkritik aturan yang ada, membuat aturan baru dan membimbing perluasan cakupan due process ke situasi kelembagaan baru merupakan sumber utama. Demikian pula, generalisasi tujuan dari fleksibilitas dalam, organisasi modern. Misalnya, sebuah universitas mengambil langkah menuju sifat responsif ketika itu menyadari perlunya membedakan apa yang benar-benar penting untuk pendidikan tinggi dari apa yang sudah biasa dan rutin dilakukan oelh universitas tersebut. Sebaliknya, birokrasi dikritik karena cendrung untuk merubah sasanan. Sementara aturan dan berbagai tujuan operasional yang menjadi tujuan. Namun, bentuk tatanan hukum yang tanggap tersebut sulit diwujudkan. Institusi-institusi dan birokrasi sangat rentan karena banyaknya perilakuperilaku pelanggar hukum. Pengaruh Ilmu dan teknologi yang terus berkembang, memungkinkan modus operandi kejahatan yang semakin kompleks. Kondisi politik (partisipasi politik) menjadi sangat menentukan, terutama dalam kaitannya dalam penyelenggaraan keadilan dan ketetertiban bagi rakyat. Tatanan hukum yang represif menunjukkan otoriternya kekuasaan. Pelaksanaan hukum otoriter di masyarakat memerlukan syarat-syarat yang relatif besar, seperti pemaksaan, mematikan kreatifitas dan pola pikir serta biaya-biaya lain yang merugikan hukum dan masyarakat sehingga masyarakatlah yang harus menanggung kerugian. Model yang cukup ideal adalah tatanan hukum yang otonom, karena tatanan hukum ini memberikan kemungkinan untuk mewujudkan ketertiban instutusional yang stabil dan tahan lama. Tatanan hukum otonom adalah suatu bentuk hukum sebagai institusi yang dirancang untuk mampu melunakkan represif dan melindungi integritas. Hukum responsif memiliki kelemahan pula. Konsep hukum responsif kurang mantap dan sangat rentan, 
mengingat kelemahan-kelemahan dan sangat rapuhnyajaring-jaring penunjang untuk mewujudkan tatanan hukum tersebut.

Dalam kaitannya dengan hal di atas, negara berdasarkan hukum adalah suatu konsep normatif yang abstrak dan dalam realitasnya diisi oleh keadaan tingkat perkembangan sosial, politik dan ekonomi dari bangsa bersangkutan. Meskipun Nonet-Selznick menguraikan bahwa, Rule of Law sebaiknya dipahami sebagai suatu sistem kelembagaan khusus, bukan sebagai suatu cita-cita abstrak. Karakteristik utama dari sistem ini adalah terbentuknya institusi hukum yang terspesialisasi, yang relatif otonom dan memiliki keunggulan serta memiliki bidang kompetensi tertentu. Pada tahap ini, konsolidasi dan pembelaan otonomi kelembagaan merupakan titik berat perhatian pars pejabat hukum. Istilah ini menunjuk pada kelemahan sekaligus kekuatan dari Rule of law. Deskripsi dan kategorisasi Nonet Selznick dalam tipe-tipe hukum yang represif, otonom dan responsif sangat membantu memahami posisi kita sebagai suatu negara hukum dengan baik. Maksudnya kehadiran tipe hukum represif, otonom atau responsive demi mewujudkan tujuan hukum masyarakat dapat diterapkan terhadap persoalan apa yang memerlukannya.

\section{Keimpulan}

Tipe tatanan hukum dari perspektif pemikiran Nonet dan Selznick yang tepat untuk diterapkan di Indonesia sekarang ini guna memberikan rasa keadilan bagi masyarakat sesuai dengan cita hukum bangsa Indonesia dapat diterapkan ke-tiga tipe hukum tersebut yakni represif, otonom dan responsive dilihat dari atau terhadap persoalan apa yang memerlukannya dalam rangka memberikan keadilan bagi seluruh masyarakat Indonesia yang belandaskan Pancasila dan Undang-Undang Dasar Negara Republik Indonesia Tahun 1945. 


\section{Daftar Pustaka}

Antasari, Rr Rina. "Penanganan Tindak Pidana Perdagangan Orang Dalam Perspektif Global Dan Islam Di Provinsi Sumatera Selatan." Kafaah: Journal of Gender Studies 8.1 (2018).

Brugginnk, J.J H,. 1996. Refleksi tentang Hukum. Bandung: Citra Aditya Bakti.

Hadi, Abdul. "Posisi Wanita Dalam Sistem Politik Islam Perspektif Fenomelogi”. An Nisa'a 12, no. 1 (October 12, 2017): 9-20. Accessed Dec 20, 2019. http://jurnal.radenfatah.ac.id/index.php/annisa/article/view/ $\underline{1500}$

Ibrahim, Jonny. 2006. Teori dan Metodologi Penelitian Hukum Normatif. Surabaya: Bayumedia Publishing.

Kebung, Konrad SVD. 2008. Rasionalisasi dan Penemuan Ide-Ide. Jakarta: Prestasi Pustaka.

Lukito, Ratno. 2008. Hukum Sakral dan Hukum Sekuler: Studi Tentang Konflik dan Resolusi dalam Sistem Hukum Indonesia. Jakarta: Pustaka Alvabet.

Rahardjo, Satjipto. 2013. Ilmu Hukum. Bandung: Citra Aditya Bakti.

Sameko, FX. Adji. 2003. Studi Hukum Kritis, Kritik Terhadap Hukum Modern. Semarang: Badan Penerbit UNDIP.

Soepomo. 2000. Bab-bab Tentang Hukum Adat. Jakarta: Pranadnya

Marzuki, Peter Mahmud. 2009. Penelitian Hukum. Jakarta: Kencana.

Neumann, Franz. 1966. The Rule Of Law, Political Theory and the Legal System in Modern Society. Berg Publisher Ltd, Spa.

Peters, A.A.G \& Koetirlani Siswosoebroto. Hukum dan Perkembangan Sosial. Jakarta: Pustaka Sinar Harapan.

Philipe, Nonet, and Philip Selznick. 2008. Hukum Responsif. Bandung: Nusa Media.

Pound, Roscoe. 1959. Jurisprudence. St. Paul Minn, West Publishing.

Pound, Roscoe. 1994. The Task of Law. Lancaster. Pennsyvania: Frankin and Marshal College.

Wahid, Marzuki \& Rumadi. 2001. Fiqh Mazhab Negara: Kritik atas Politik Hukum Islam di Indonesia. Yogyakarta: LkiS. 